\title{
The Implementation of CORE Model to Improve Students' Mathematical Problem Solving Ability in Secondary School
}

\author{
AnisaWijayanti \\ Department of mathematics education \\ Indonesia University of Education \\ Bandung, Indonesia \\ wijayanti.anisa@yahoo.com
}

\author{
Tatang Herman \\ Department of mathematics education \\ Indonesia University of Education \\ Bandung, Indonesia \\ tatangherman@upi.edu
}

\author{
Dian Usdiyana \\ Department of mathematics education \\ Indonesia University of Education \\ Bandung, Indonesia \\ dianusdy@yahoo.com
}

\begin{abstract}
This research was conducted because the students' mathematical problem solving ability in secondary school is low. The goal of this research is to examine the enhancement of student mathematical problem solving ability after students learned using the CORE Model. The research method of this research was quasi experimental method. Population used in this research was all eight graders in a public secondary school in Bandung. The purposive sampling technique was used to derive at samples of two classes categorized into experimental and control classes. The experimental class learned using the CORE Model, while the control class learned using the conventional model. Data analysis was done by comparing the improvements in mathematical problema solving abilities between the experimental class and the control class through a series of tests examined statistically and analyzed using average normalized gain. Student's responses were assessed by means of questionnaires, observation sheets and interviews. The results showed that CORE Model was able to improve the problema solving ability as the average grade for the experimental class is higher tan that of the control class. Furthermore, students showed positive responses toward the CORE Model.
\end{abstract}

Keywords- CORE (Connecting, Organizing, Reflecting, Extending) model; mathematical problem solving ability; conventional model

\section{INTRODUCTION}

Mathematics learning cannot be detached from problem solving because someone's success in mathematics is marked by the existence of problem solving ability. This is because problem solving is not only a concept application at the end of a topic, but it also an inseparable part in every mathematics sub-topic in schools. In conjunction with its relation in every mathematics topic, problem solving also plays an important role in mathematics because a lot of problems in daily life needs mathematics involvements to solve. Therefore, problems solving becomes a continuing issue in which solutions are always be sought [1].

In light of the importance of problem solving ability, the test result of the preliminaryresearchaboutstudent problem solving ablityin some school in Bandung showed that their ablity was low, especially in the topic of geometry. Many research have been developed to improve this ability but the result wasn't good enough [12]. The result of interviewed the teacher showed that this problem occur because the teachers have difficulties to finding the best method to teach it and it is relevance with research by Sulistiawati [14] that said that $43,7 \%$ teachers in Secondary School need training to improve their ability to teach the topic of geometry.

The students' low problem solving abilityin the topic of geometry need the solution. If we concern in problem solving, we will know that problem solving ability can be obtained if good communication between teachers and students and among students are well established so that it will stimulate students' participations. It means that in order to improve problem solving ability, teachers have to choose a model that can make the learning situation focus on students or student centered.

CORE Model that focus on activity to find solution in a group and class discusionwhich consists of four processes: Connecting (to relate new and old information), Organizing (knowledge organization process with the student experience to solve their problem and construct their knowledge), Reflecting (to reflect gained knowledge when their rethink again about the solution after their found it), and Extending (to broaden knowledge) after group and class discussion with the individual test is a model that gives students room to opine, to construct their knowledge by themselves and to solve problem in group discussion also to give opportunities to students to 
reflect learning results, to check the correctness of the answers in a class discussion and to expand knowledge independently [4]. This provide different experince which hopefully can increase students'problem solving ability because the knowledge and the scheme of it can be formed by the experience. It also related to Piaget theory that said that every children learn something by the experience of it. And this process must involving their sensory with a group discussion or activity [13]

Many research have been developed to explore the effect of CORE model, one of it is about CORE model to improve student's ability in the science topic [16]. And the effectiveness of CORE model in topic of function [15]. But, if we focus on the syntaxes of CORE model. We will see that those syntaxes is also related with Polya steps so the hyphotesis is CORE model can improve the student's problem solving ability.

In this research, researcher will discuss about the implementation of CORE model to improve mathematical problem solving ability within Secondary School students. Hence, the research questions are: (1) How is the improvement in students' mathematical problem solving ability after they learned with CORE model? (2) Whether the mathematical problem solving ability of the students who learn with the CORE model are better than those of students with conventional model? (3) What are the students' responses towards CORE Model compared to the traditional methods?

\section{Mathematical Problem Solving}

To give an understanding about problem solving, it should first be preceded by an explanation about the definition of a problem. Newell \& Simon [5] stated that "A problem is a situation in which an individual wanted to do something but he or she does not know how and what necessary actions needed to achieve what he or she wants". Problem solving is a process to answer non-routine problems in which students are asked to determine strategies and implement those strategies to attain solutions. To find a solution, students need to use concepts that they previously learned and through a process where they develop new mathematical understandings. Problem solving was not only the goal of learning mathematics but also had a more important meaning from the working process [6].

Altun [7] revealed that there are three conditions of a problem for students: it is difficult for the person who encounter it, questions provided to students need to be understood by the students, but at the same time, challenging enough for them to answer, Subsequently, the given questions must not be possible to be answered by routine procedures known to students.

Polya[8] separated the mathematical problems into two"; (1)Problem to find. It included the theory of problem, practice, abstract, and real. Before solving the problem, we must find variable of problem and reconstructed all object to solve the problem. The main questions needed to solve the problem were: what are we looking for? what are the identified data? what is the qualification? This category of problems was better applicable in elementary mathematics (2) Problem to prove.
Student should prove a statement whether it is right. The main parts in this problem were the hypothesis and conclusion of the theory that should be proven.

Polya stated that solving problem was a way to learn about methods or rules to discover or find the solution. Problem solving ability mean students' abilities to solve problems by using Polya's steps. According to Polya [8], there were four steps that can be followed:

1. Understanding the problem was to identify what are the known data, what data that could be asked, what conditions that were in place and whether conditions could be satisfied, to evaluate whether the known conditions were sufficient to find the unknown and restate original problem in a more applicable form.

2. Plan strategy to solve problems. To ensure whether problems were known or to see the same problems with a different angle and to relate problems with theory.

3. Doing the plan. Checking every step and proving that the steps were true.

4. Looking back (double check) to recheck the solution of the problem, the results, and the arguments. In this section, students could share their solutions to the other students.

The solution to problem's indicators used in this research as quoted from Sumarmo [9] are as follows: (1) Identifying adequate data to solve problems. (2) Making mathematics model from the daily situation. (3) Choosing and applying strategy to solve mathematics problem or another problem. (4) Describing and interpreting the result. (5) Implementing mathematics in every situation

\section{Core Model in Learning Mathematics}

In learning activities, teachers should create a comfortable situation for their students. In addition, teachers should apply learning strategy or models that can help students to map out learning materials in her memories and help students to connect one material to another and draw conclusion from each material that has been given. It is in accordance to Jacob's opinion [10] which determined that students' knowledge will be increased and saved in their memory if only the social environment is good and teachers should help students in reflecting what students have been studying in the learning process. Teacher also has to be able to connect concept patterns and increase student's knowledge.

The activities that make students actively participate and reflect what they have been learning can be done through discussion activity. Discussion is an activity attended by two or more people to share ideas and experiences and to broaden knowledge. Discussion method is a teaching strategy that connects problems that trigger discussions in the first place to come up with an agreed-upon decision or opinion [11]

Calfee and Miller [4] suggested a learning model that utilized discussion method to influence the knowledge growth by involving students that is called CORE." learning process within CORE model supports students to reconsturct 
knowledge through the connection between the old and new information (Connecting), organize a number of various materials (Organizing), reflect everything that the students learned (Reflecting), optimize learning environment and expand problem solving ability independently through individual assignment at the end of the lessons (Extending).

In the process of teaching and learning mathematics in the class, the implementation of CORE model can be devided in three session those are; group discussion, class discussion and individual task. First, the teacher ask to the student to make a group discussion consist of four or five person. Then, when the groups have been made. The teacher can tell something about the material that the student will learn and give the problem in the worksheet. The student have to solve it in group discussion. They can share their idea, try and do more in group. Then when the solution was found, the teacher ask to find another solution and then rethink again about the solution that they've found. After this, the second is class discussion, the student have to share their idea in solve the problem in class discussion and make the conclussion or best solution. Third, is whenthe student have to work individually to solve the broaden problem by themselves. This process is important to know how the student learn in the step before. Whether they understand about the material and the topic of the discussion or not. If they understand it, the student can use the strategy that they have learnd to solve the new problem. This activity will improve the student problem solving ability because every student have try to solve problem by themselves with new knowledge that they've got before.

\section{RESEARCH METHOD}

Research method used in this research was quasi experimental. The design used in this research was nonequivalent design. Population in this research was all of the students of SMPN 9 Bandung. The school was a second cluster school in which new students were selected based on the National Uniform Examination or Ujian Akhir Nasional (UAN) grades, end of semester exam grades, and report card grades. Samples in this research were two classes of eight grader selected based on purposive sampling technique. These classes were selected by the principal and teachers in order to decide which class would become the experimental class and which one was the control class. Experimental class learned mathematics using CORE model and the control class used the conventional model.

The topic of this research is about geometry in eight grade of Secondary School. The instruments used in this research were the test instruments, observation forms, questionares, and interviews. The test instrument test consisted of pre-test and post-test. Pre-test was given before they learn geometry with CORE model and conventional model and the post-tes was given when the students have learned it. The test consisted of five essay questions within indicators from KTSP standard and mathematics problem solving ability. Observation form was used to evaluate conformity between learning process and the related lesson plans as well as to determine the suitability between the learning process and the predetermined CORE model steps. The observer was someone who knows the steps of CORE model. Questionnaire consist of close expression and the student have to choose it. Questionaire was given to the students in the experimental class to collect their response to the CORE model. Interviewsconsist of open question were conducted to the students who got the best and the lowest post test results to know the main factor of it.

\section{RESULTS AND DISCUSSION}

\section{A. Result}

Data from this research have been analyzed by statistics and the improvement of problem solving ablitity was analyzed by Normalized gain, $g$ is defined as $g=\frac{\text { posttest-pretest }}{\text { ideal score-pretes }}$. The mean result from gain formula in this research was 0.3 , which means it is low. The gain index interpretation for mathematical problem solving ability fell within all three categories of improvement where $16 \%$ fell within high category, $31 \%$ within middle category and $53 \%$ within low category.

The increase in mathematical problem solving ability in both CORE model learning students (experiment class) and conventional learning students (control class) varies significantly. The descriptive statistics of postes shown in Table I.

TABLE I. DESCRIPTIVE STATISTICS OF POSTTEST IN EXPERIMENT CLASS AND CONTROL CLASS

\begin{tabular}{|l|l|l|l|}
\hline \multicolumn{2}{|c|}{ Classes } & \multicolumn{1}{c|}{ Statistic } & Std. Error \\
\hline \multirow{4}{*}{ Experimental } & Mean & 42.3913 & 4.09135 \\
\hline & Median & 32.2200 & \\
\hline & Variance & 535.653 & \\
\cline { 2 - 4 } & Std. Deviation & 23.14418 & \\
\hline & Minimum & 13.33 & \\
\hline & Maximum & 96.66 & \\
\hline \multirow{5}{*}{ Control } & Mean & 30.8981 & 3.59951 \\
\hline & Median & 21.6650 & \\
\hline & Variance & 414.606 & \\
\hline & Std. Deviation & 20.36189 & \\
\hline & Minimum & 8.88 & \\
\hline & Maximum & 93.33 & \\
\hline
\end{tabular}

After we get descriptive statistic of posttes data. We will check the normality of it withTest of Normality Posttes of Experiment Class and Control Class, and the result showed in Table II.

TABLE II. TEST OF NORMALITY POSTTEST

\begin{tabular}{|c|r|r|r|}
\hline \multirow{2}{*}{ Classes } & \multicolumn{3}{|c|}{ Shapiro-Wilk } \\
\cline { 2 - 4 } & Statistic & \multicolumn{1}{|c|}{ Df } & \multicolumn{1}{c|}{ Sig. } \\
\hline Experimental & .900 & 32 & .006 \\
\hline Control & .838 & 32 & .000 \\
\hline
\end{tabular}

Based on the table 2 we know that significant value of experiment class is 0.006 and control class is 0.000 . this value is less than 0.05 so the data is not normal. Because of it we will get Mann-Whitney $U$ test. The result of it will shown in Table III. 
TABLE III. MANN WHITNEY-U

\begin{tabular}{|c|r|}
\hline & \multicolumn{1}{|c|}{ Postes } \\
\hline Mann-Whitney U & 336.000 \\
\hline Wilcoxon W & 864.000 \\
\hline Z & -2.365 \\
\hline Asymp. Sig. (2-tailed) & .018 \\
\hline
\end{tabular}

Based on the Table III, significant value was 0.018 (half of it was 0.009). It means that the class with CORE model learning activities is better than the class with conventional learning activities.

The result of questionnaire data processed based on Likert's scale and it showed that $97 \%$ of students showed positive response and only one student or $3 \%$ showed negative response. It means that the students'response in learning with model CORE is good and they apreciate it.

\section{B. Discussion}

The result show thatgain index is 0.3 which is interpreted as low. The average normalized gain shows that $53 \%$ of student exhibited small increase of problem solving ability. It means the CORE model fails to increase mathematical problem solving ability significantly. From the learning process point of view, the main factor that caused the mathematics problem solving ability does not increase significantly is the low learning motivation. Students did not review the material given in class activities. This fact is in accordance to the interview results of students with low marks. They acknowledged that they did not review material given in class activities. They also say that they did not study well when they were going to take the test. The lowness of students' learning motivation also leads to students' failure in concentrating during the learning process.

The mathematical problem solving ability in the experimental class showed better improvement compared to that of control class because of the use of CORE model which stands for Connecting, Organizing, Reflecting and Extending and student-activity based lessons which helps enhancing students' concentrations on the materials being taught. Students can express their ideas to solve problems and demonstrate their ideas to other students. Students who seem difficulties are allowed to ask their peers. These facts are found based on student's interview result and resume from questionnaire.

According to its syntax, CORE model relates to Polya's steps (1945) in terms of mathematical problem solving. The steps are: (1) understanding the problem; (2) planning the solution; (3) performing the plan; (4) looking back. Connecting process is closely related to Polya's first step, "understanding the problem". Connecting is done in the beginning phase of learning when students try to understand the problem and get to know the data. During this process, students solve problem and also gain deeper understanding of relations among available materials so that students can draw conclusion on each meeting. Organizing process is connected to the second and the third step of Polya, "planning the solution" and "doing the plan". Organizing process in group discussion and class discussion make students learn better. In this process, student can express their ideas and opinion about problem solving strategy and accept other students' ideas and opinions. Reflecting process is connected to the fourth step Polya steps, looking back. In this process, students review the previous steps, understand the material of discussion, understand other student's learning strategy, and choose a right strategy. So, the students can find the error path and try to fix the error. Extending process is the final step in CORE model learning activities. In this step student can use the wide strategy to solve the problem, which will make their learning abilities increase. According to this description, connecting, organizing and reflecting process help influencing students to do the test.

The students' response to CORE model learning activities was positive. Ninety-seven percent of the students claimed that they were more comfortable when learning with CORE model than learning with conventional model. According to questionnaire and interview, CORE model could make students think positively about mathematics and problem solving. CORE model can reduce negative attitude toward mathematics, including boredom. Unfortunately, CORE model does not improve students' motivation in learning significantly. Students did not review the material that given in previous meeting. Students' motivation only appears when learning activities are being held.

Beside the lowness of students' motivation, the duration in learning activities wasn't enough. So, student can't solve the problem during learning activities. Students also rarely asked to teacher when they find problem which can't be done. To improve students' motivation, and find the solution about students' learning weakness significantly, we should hold the research about pre study students' learning motivation with CORE model.

\section{CONCLUSION}

According to the analysis of research process in Secondary School, there are three conclusions, (1) students who get CORE model learning activities improve their problem solving ability; (2) students' mathematical problem solving ability with CORE model learning activities improves compared to that of students with conventional model; (3) students have positive response to the CORE model learning activities.

\section{References}

[1] J. Cai, "Singaporean students' mathematical thinking in problem solving and problem posing: An exploratory study," International Journal of Mathematical Education in Science and Technology, 34(5), pp. 719-737, 2003.

[2] S.Provasnik, D.Kastberg, D.Ferraro, N.Lemanski, S.Roey, and F.Jenkins, Highlights from TIMSS 2011: Mathematics and Science Achievement Of U.S. Fourth-And Eighth-Grade Students in an International Context (NCES 2013-009), Washington, DC: National Center for Education Statistics, Institute of Education Sciences, U.S. Department of Education, 2012.

[3] OECD, PISA 2009 at Glance,OECD Publishing, 2010

[4] Calfee, R.V.dan Miller R.G., Making Thinking Visible, National Science Education Standards. University of California Riferside. Jakarta: Kementrian Pendidikan dan Kebudayaan, 2004. 
[5] A.Newell \& H.Simon, Human Problem Solving: The State of The Theory. American Psyichologist, Carnegic-Melon University, pp145160, 1971.

[6] National Council of Teacher of Mathematics. Principles AndStandars For School Mathematics. Reston, Va. 2000.

[7] M.Altun, Mathematics Teaching for Education Faculties and Primary Teachers. Bursa: Actuel Publication, 2005.

[8] G.Polya, How To Solve It: A New Aspect of Mathematics Method (2nd Ed) Princenton, New Jersey :Princenton University Press. 1945.

[9] U. Sumarmo, dan H.Hendriana,Penilaian Pembelajaran Matematika. Bandung: PT Rafika Aditama, 2014.

[10] C.Jacob, "Development of CORE model through learning logic with reciprocal teaching approach within SMAN 9 Bandung and SMAN 1 Lembang," unpublished

[11] Y,Nursidik, "Discussion method of learning," unpublished

[12] Mulyana, Tatang. "Pengembangan Bahan Ajar Melalui Penelitian Desain". Jurnal Ilmiah Program Studi Matematika STKIP Siliwangi Bandung, Vol 1, No.2, September 2012

[13] Santrock, John W. Life Span Development (Perkembangan Masa Hidup) Jilid I. AlihBahasa: Benedictine Widyasinta Jakarta: Erlangga, 2014

[14] Sulistiawati,"PengembanganDesainDedaktisKemampuanPenalaranMate matispadaMateriLuasdan Volume Limas. "unpublished
[15] [15] Mayasari, "Efektivitas Model Pembelajaran Kooperatif Tipe Core (Connecting, Organizing, Reflecting, Extending) Pada Materi Pokok Fungsi Di Sma Negeri 1 Campurdarat" unpublished

[16] [16] Sumaji, "Upaya Meningkatkan Prestasi Belajar Ipa Materi Ketergantungan Manusia Dan Hewan Pada Tumbuhan Hijau" Melalui Metode Connecting, Organizing, Reflecting, Dan Extending SiswaKelas V, Jurnal PINUS Vol. 1 No. 2, 2015 